\title{
The Brain Ischemic Volume Correlation with the Ischemic Modified Albumin Level
}

\section{İskemik Beyin Hacminin İskemik Modifiye Albümin Seviyesi ile Korelasyonu}

\author{
(D) Burak Demirci', (D Muhammed Evvah Karakılıç², (D) Abuzer Coşkun¹, (D Cihat Yel3,

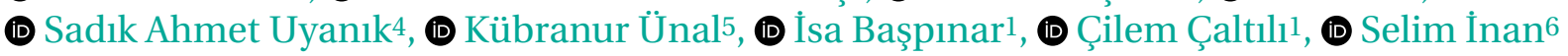

\author{
${ }^{1}$ University of Health Sciences Turkey, İstanbul Bağcllar Training and Research Hospital, Clinic of Emergency Medicine, İstanbul, Turkey \\ 2Eskişehir Osmangazi University, Training and Research Hospital, Clinic of Emergency Medicine, Eskişehir, Turkey \\ 3 Ankara Numune Training and Research Hospital, Clinic of Emergency Medicine, Ankara, Turkey \\ ${ }^{4}$ Okan University Hospital, Clinic of Radiology, İstanbul, Turkey \\ ${ }^{5}$ Ankara Duatepe Polatlı State Hospital, Clinic of Medical Biochemistry, Ankara, Turkey \\ ${ }^{6}$ Ankara Training and Research Hospital, Clinic of Emergency Medicine, Ankara, Turkey
}

\section{Abstract}

Objective: Cerebrovascular disease is a frequent cause of emergency department visits, and early diagnosis can reduce mortality and morbidity. It was aimed to evaluate the relationship between diffusionweighted-magnetic resonance imaging (DW-MRI) and blood ischemic modified albumin (IMA) levels of cerebrovascular diseases in terms of demographic characteristics, mortality, and morbidity.

Method: This prospective cohort study included 44 patients diagnosed with ischemic stroke in the emergency room between January and July 2014 and 44 people in the control group. Age, gender, vital signs, comorbid disease states, neurological deficit levels, IMA levels, DW-MRI involvement volumes, and mortality rates were analyzed in patients who were diagnosed with stroke and who had DW-MRI restrictions. Also, a control group of 44 volunteers who applied to our emergency department was added to compare the IMA level.

Results: The median age of the patients was 71 years (24 males, 20 females, range 47 to 83 years) and the median age of the control group was 68 ( 25 males, 19 females, range 52 to 79 ) years. The median age of the control group was close to that of the patient group, the two groups were also similar in terms of gender distribution. The most common comorbid disease was hypertension 28 (63.6\%), atrial fibrillation (AF) 14 (31.8\%), diabetes mellitus (DM) 10 (22.8\%) and coronary artery disease 10 (22.8\%). The median value of the IMA level was 13.84 in the patient group and 8.66 in the control group. While the patients' NIHSS stroke score was high, the area of involvement in MRI and also IMA levels increased.

\section{Öz}

\begin{abstract}
Amaç: Serebrovasküler hastalık, acil servis başvurularının sık bir nedenidir, erken tanı mortalite ve morbiditeyi azaltabilir. Çalışmamızda serebrovasküler hastalıkların difüzyon ağırlıklı-manyetik rezonans görüntülemeleri (DA-MRG) ile kan iskemik modifiye albümin (IMA) düzeyleri arasındaki ilişkinin demografik özellikler, mortalite ve morbidite açısından değerlendirilmesi amaçlandı.
\end{abstract}

Yöntem: Bu prospektif kohort çalışmasına Ocak-Temmuz 2014 tarihleri arasında acil serviste iskemik inme tanısı almış 44 hasta ile 44 kontrol grubu dahil edildi. İnme tanısı konulan ve DA-MRG kısıtlaması olan hastalarda yaş, cinsiyet, yaşamsal belirtiler, yandaş hastalık durumları, nörolojik defisit düzeyleri, IMA düzeyleri, DA-MRG tutulum hacimleri ve mortalite oranları analiz edildi. Ayrıca, iMA düzeyini karşılaştırmak için acil servisimize başvuran 44 gönüllüden oluşan bir kontrol grubu eklenmiştir.

Bulgular: Hastaların ortalama yaşı $66,98 \pm 16,36$ ve $\% 54,5^{\prime} i \quad(n=24)$ erkekti. Kontrol grubu ile hasta grubunun yaşları benzerdi. En sık görülen komorbid hastalık hipertansiyon 28 (\%63,6); atriyal fibrilasyon 14 (\%31,8), diabetes mellitus $10(\% 22,8)$ ve koroner arter hastalığı $10(\% 22,8)$ idi. IMA düzeyinin ortanca değeri hasta grubunda 13,84 , kontrol grubunda 8,66 idi. Hastaların NIHSS inme skoru yüksek iken, MRG'deki tutulum alanı ve ayrıca IMA seviyelerinin arttığı görüldü. Ayrıca difüzyon kısıtlama alanı ve iMA düzeyleri pozitif ve orta düzeyde ilişkiliydi.

Sonuç: IMA düzeyi, akut iskemik inmede kullanılabilen bir parametre ve DA-MRG'de kısıtılık alanının bir göstergesi olarak değerlendirilebilir.

Address for Correspondence: Burak Demirci, University of Health Sciences Turkey, İstanbul Bağcılar Training and Research Hospital, Clinic of Emergency Medicine, İstanbul, Turkey

E-mail: drburakdemirci@hotmail.com ORCID: orcid.org/0000-0001-6658-7260 Received: 01.10.2020 Accepted: 11.11.2020

One of the authors of this article $(\mathrm{AÇ})$ is a member of the Editorial Board of this journal. He was completely blinded to the peer review process of the article.

Cite this article as: Demirci B, Karakılıç ME, Coşkun A, Yel C, Uyanık SA, Ünal K, Başpınar İ, Çaltılı Ç, İnan S. The Brain Ischemic Volume Correlation with The Ischemic Modified Albumin Level. Bagcilar Med Bull 2021;6(1):26-31.

(C) Copyright 2021 by the Health Sciences University Turkey, Bagcilar Training and Research Hospital Bagcilar Medical Bulletin published by Galenos Publishing House. 


\section{Abstract}

Besides, diffusion involvement area and IMA levels were positively and moderately correlated.

Conclusion: IMA level can be considered as a parameter that can be used in acute ischemic stroke and as an indicator of the diffusion restriction area in MRI.

Keywords: Acute ischemic stroke, biomarkers, diffusion-weighted magnetic resonance imagining, ischemic modified albumin

\section{Öz}

Anahtar kelimeler: Akut iskemik inme, biyobelirteçler, difüzyon ağırlıklımanyetik rezonans görüntüleme, iskemik modifiye albümin

\section{Introduction}

In acute cerebrovascular events, definitive diagnosis and treatment processes should be started immediately as soon as the patient's clinic begins. The primary aim of the diagnostic procedure is to clarify whether the clinical condition is a result of ischemic disease or another neurologic or metabolic condition. The sensitivity of agood physical examination is $99 \%$ and the specificity is $85 \%$, which cannot differentiate the ischemic and hemorrhagic causes of the stroke (1). Computed tomography (CT) is used as the first choice for the differentiation of ischemic and hemorrhagic stroke (2). The sensitivity and specificity of the CT for the ischemic cerebrovascular diseases (CVD) are $39.8 \%$ and $91.7 \%$, respectively, in the first six hours; with repetition of CT between 6 and 24 hours, the sensitivity and specificity increases slightly but still not enough for exact diagnosis (3). In the first six hours, we use DW-MRI, which has a sensitivity of 58.3 to $97.3 \%$ and specificity of $100 \%$ (3).

The delay in the diagnosis and treatment of CVD is generally observed in transportation to the hospital and the evaluation of the diagnostic tests in the hospital (4). Despite the usage of all diagnostic methods, the etiologic reason cannot be specified in $20 \%$ of the CVD (5). Therefore, some new biomarkers that can be useful for an early diagnosis such as ischemic modified albumin (IMA) are investigated (6) in CVD patients. IMA is a sensitive biomarker that has shown the increase in some ischemic conditions such as myocardial ischemia, muscle ischemia, pulmonary embolism, mesentery ischemia, and cerebral ischemia (6).

The study aimed to investigate the relationship of IMA levels with DW-MRI findings and demographic characteristics in terms of morbidity and mortality in patients admitted to the emergency department due to cerebrovascular stroke.

\section{Materials and Methods}

\section{Study Design and Population}

After local ethics committee approval was received for this prospective study, 88 patients, (44 patients, and 44 controls) who were admitted to the emergency department between January and July 2014, were included. After informing the patients and controls voluntarily, the "information consent form" was signed and included in the study.

In addition to patients who did not have DW-MRI and whose IMA levels were not considered, patients with endocrine pathology, psychiatric drug use, chronic liver disease, need for dialysis, central nervous system infection, chronic inflammatory disease, malignancy, severe anemia, hematological disease, severe dietary history, radiotherapy in the head and neck region, and pregnancy were not included in the study.

The National Institutes of Health Stroke scale (NIHSS) score was used in the definition of cerebrovascular stroke in the patient group. NIHSS score was classified as no symptoms if 0 , minor stroke if 1-4, moderate stroke if 5-15, moderateheavy stroke if 16-20, and heavy stroke if 21-42 (7). Forty four healthy volunteers who did not have any ischemic disease were included in the study.

\section{Laboratory Design}

The venous samples of the patients taken to a plastic gel vacuum tube were kept for 20 minutes at room temperature to complete the coagulation. The samples were centrifuged at 4.000 cycles for 10 minutes, hemolyzed or icteric samples were excluded and repeated from the same patient. The IMA level was detected by Tweak original commercial kits by enzyme-linked immunosorbent assay (ELISA) method. The IMA level measurement was performed by putting the ELISA kit (Eastbiopharm, Hangzhou Eastbiopharm Co. Ltd. China, ref: CK-E90172, lot: 201402) on the BioTEK Plate reader. The blood serum samples were incubated in microplate wells that were covered by antibodies 
identifying IMA antigen for 30 minutes at $37^{\circ} \mathrm{C}$. After the washing process, entrapped IMA antigens were incubated by adding the anti-human IMA antibodies that were conjugated with horseradish peroxidase for 30 minutes at $37^{\circ} \mathrm{C}$. Following this step, the chromogen $\mathrm{A}$ and B solutions were added and incubated for 15 minutes at $37^{\circ} \mathrm{C}$. The reaction was aborted by a stop solution. The absorbance of the yellow-colored product was measured by the spectrophotometric method at $450 \mathrm{~nm}$ wavelength. The absorbance was proportioned with IMA concentration. We obtained a standard calibration curve by marking the IMA standard concentration points. The unknown blood serum concentrations were determined by this obtained standard curve. The measurable concentration range of the ELISA kit was 1-60 U/mL, the lower limit of quantification was $1 \mathrm{U} / \mathrm{mL}$.

\section{Radiological Design}

DW-MRI procedures were performed by $1.5 \mathrm{~T}$ General Electric $\left(\mathrm{GE}^{\circledR}\right)$ MRI Machine. Hyperintense signal variances in apparent diffusion coefficient images were accepted as a diffusion restriction or a new infarct area. The infarct volume was calculated by $\mathrm{ABC} / 2$ formula, which is a fast method for estimating the affected volume of intracerebral area. This simple method provides a $3 \mathrm{D}$ analysis of the intracerebral area.

$\mathrm{A}$; is the greatest hemorrhage diameter.

$\mathrm{B}$; is affected area's diameter 90 degrees to A in the axial plane.

$\mathrm{C}$; is the approximate number of CT slices with hemorrhage multiplied by the slice thickness.

The multiplication of A, B, and C were divided by 2 and the final result was accepted as the volume of the infarct region (8). Besides, measurements were made in centimeters $(\mathrm{cm})$, then the formula gave the results as cubic centimeters $\left(\mathrm{cm}^{3}\right)$.

\section{Statistical Analysis}

All statistical analyses were calculated with SPSS 18.0 for Windows (New York, USA). Continuous variables were expressed as mean \pm standard deviaton, and categorical variables as $\mathrm{n}(\%)$. Median and minimum-maximum limits were given for age. Normal distribution was determined by the Kolmogorov-Smirnov test advertising histogram. Differences of continuous variables between the groups were calculated by the Mann-Whitney U test and KruskalWallis test for non-normally distributed variables; student's t-test was used for normally distributed data; chi-square test was used for categorical variables. Correlations of continuous variables were calculated with the Pearson's correlation. $\mathrm{P}<0.05$ was considered significant at $95 \%$ confidence interval.

\section{Results}

The median age of the patients was 71 years (24 males, 20 females, range 47 to 83 years) and the median age of the control group was 68 ( 25 males, 19 females, range 52 to 79) years. The median age of the control group was close to that of the patient group; The gender distributions of the two groups were similar $(\mathrm{p}=0.830$, Table 1$)$.

The most frequently observed co-morbidity in the patient group was hypertension with a rate of $63.6 \%(\mathrm{n}=28)$; followed by AF, 31.8\% ( $\mathrm{n}=14), \mathrm{DM}, 22.8 \%(\mathrm{n}=10)$, and coronary artery disease, $22.8 \%(n=10)$ (Table 2$)$.

When the vital signs of the patients we included in the study were examined, the mean systolic blood pressure value of the patients was $177.14 \pm 18.28 \mathrm{mmHg}$, the mean diastolic blood pressure value was $97.68 \pm 14.46 \mathrm{mmHg}$ and the heart rate was $89.02 \pm 9.1$ beats/minute as seen (Table 3 ).

The median IMA level was 13.84 U/mL (range 6.25-209.72 $\mathrm{U} / \mathrm{mL}$ ) in the patient group and $8.66 \mathrm{U} / \mathrm{mL}$ (range 1.79$49.58 \mathrm{U} / \mathrm{mL}$ ) in the control group (Table 4 ).

IMA level was significantly higher in the patient group $(p<0.001)$. While the NIHSS score was increasing the ischemic volume in DW-MRI, IMA level showed the increase

\begin{tabular}{|c|c|c|c|}
\hline & $\begin{array}{l}\text { Patient } \\
\text { Median } \\
(\text { min-max)/n (\%) }\end{array}$ & $\begin{array}{l}\text { Control } \\
\text { Median } \\
\text { (min-max)/n (\%) }\end{array}$ & $p$ \\
\hline Age & $71(47-83)$ & $68(52-79)$ & - \\
\hline Gender & & & $0.830^{*}$ \\
\hline Male & $24(54.5)$ & $25(56.8)$ & \\
\hline Female & $20(45.5)$ & $19(43.2)$ & \\
\hline
\end{tabular}

Table 2. Comorbid properties of the patient group

$$
\mathrm{n}(\%)
$$

\section{Hypertension}

$28(63.6)$

Atrial fibrillation

$14(31.8)$

Diabetes mellitus

$10(22.8)$

Coronary artery disease

$10(22.8)$

Cerebrovascular disease

4 (9)

Other diseases

$4(9)$

$\mathrm{n}$ : Patients number, $\mathrm{p}<0.05$ 
(Table 5); also, there was a moderate positive correlation with ischemic volume in DW-MRI and IMA level $(\mathrm{p}<0.001$, $\mathrm{r}=0.641)$.

The mortality rate was $6.8 \%(\mathrm{n}=3)$. The IMA level and the ischemic volume in DW-MRI were similar in the dead and alive patients ( $\mathrm{p}=0.172$ and $\mathrm{p}=0.239$, respectively).

\section{Discussion}

The early diagnosis of CVD is important for reducing mortality and morbidity. According to previous study reports, there is not a significant gender difference in CVD but most of the cases are reported over the age of 65 years $(9,10)$. In our study, the median age of the patients was 71 years, males constituted $54.5 \%$ of all cases and it was found to be compatible with similar studies.

Hypertension can be observed before or after the CVD diagnosis (11-13). Only by regulating the blood pressure

Table 3. Patient's blood pressure status and pulse numbers

\begin{tabular}{lll} 
& Mean \pm SD & Min-max \\
\hline Systolic arterial pressure $(\mathrm{mmHg})$ & $177.14 \pm 18.28$ & $130-210$ \\
Diastolic arterial pressure $(\mathrm{mmHg})$ & $97.68 \pm 14.46$ & $70-130$ \\
Heart rate (beats/min) & $89.02 \pm 9.1$ & $62-104$ \\
\hline
\end{tabular}

SD: Standard deviation, $p<0.05$

Table 4. Comparison of IMA levels of patient and control groups

\begin{tabular}{llll} 
& $\begin{array}{l}\text { Patient level } \\
\text { (min-max) }\end{array}$ & $\begin{array}{l}\text { Control level } \\
\text { (min-max) }\end{array}$ & $\mathbf{p}$ \\
\hline IMA & $13.84(6.25-209.72)$ & $8.66(1.79-49.58)$ & $\mathbf{0 . 0 0 1}$ \\
\hline
\end{tabular}

$p<0.05$, IMA: Ischemic modified albumin

Table 5. The ischemic volume in DW-MRI and median IMA level according to NIHSS score

The ischemic volume

\begin{tabular}{|c|c|c|c|}
\hline & $\mathbf{n}$ & $\begin{array}{l}\text { DWMRI } \\
\text { median (min-max) }\end{array}$ & $\begin{array}{l}\text { IMA level } \\
\text { median (min-max) }\end{array}$ \\
\hline $\begin{array}{l}\text { Minor stroke } \\
\text { (NIHSS 1-4) }\end{array}$ & 16 & $3.91(1-78.14)$ & $14.42(6.25-209.72)$ \\
\hline $\begin{array}{l}\text { Moderate } \\
\text { stroke (NIHSS } \\
5-15)\end{array}$ & 15 & $9.7(1.92-24.35)$ & $8.93(6.25-25.63)$ \\
\hline $\begin{array}{l}\text { Moderate- } \\
\text { severe stroke } \\
\text { (NIHSS 16-20) }\end{array}$ & 9 & $54.88(4.3-88.2)$ & $28.75(8.93-196.30)$ \\
\hline $\begin{array}{l}\text { Severe stroke } \\
\text { (NIHSS 21-42) }\end{array}$ & 4 & $49.82(5.65-131.83)$ & $16.07(10.72-159.89)$ \\
\hline p & - & 0.002 & 0.017 \\
\hline
\end{tabular}

and controlling hypertension, we can decrease the CVD risk by up to $40 \%$ (14). Previous studies reported the mean systolic pressure on admission as around $155 \mathrm{mmHg}$ $(9,15)$. We know that CVD frequency increases with AF and DM (16) as we observed their frequency as $31.8 \%$ and $22.8 \%$, respectively, in our study. Blood pressure values were found to be slightly higher than the values indicated in similar studies. The mean systolic blood pressure value was determined as $177.14 \pm 18.28 \mathrm{mmHg}$. Also, the most common co-morbid disease was hypertension, followed by $\mathrm{AF}$ and $\mathrm{DM}$. We think that the average systolic pressure values are slightly higher, depending on the socioeconomic level and eating habits.

Free oxygen radicals produced in the process of ischemia, reperfusion, acidosis, and hypoxia lead to a structural change of transition metals like cobalt, copper, and nickel on $\mathrm{N}$-terminal end, which causes a decrease in binding of albumin to these points (17-19). The IMA level is in the normal range in healthy people but smoking, age, race or gender do not also influence the level of IMA (20). The IMA level increases in CVD, acute mesentery ischemia, acute pulmonary embolism, and acute coronary syndromes (21-23). Abboud et al. (19) reported that the IMA level increased in ischemic stroke but did not increase in hemorrhagic stroke. Gunduz et al. (21) reported that the IMA level was higher in ischemic stroke than in hemorrhagic ones and suggested to use it in differential diagnosis. IMA level was found to be high as in similar studies. We think that the reason for this is that due to increased free radicals, the protein cannot be attached to the cell, it remains free in the blood and the IMA level increases accordingly.

DW-MRI is generally used for the diagnosis of ischemic stroke in the case of CT but suspicion of ischemic CVD is still present. In ischemic CVD, while the ischemic volume increases, the clinical condition gets worse $(24,25)$. In SVO cases; as diffusion involvement became more common in DW-MRI, it was found that the NIHSS score and IMA levels increased and the patient's clinic worsened as a result. In similar studies, Can et al. (26) reported that the IMA level increased while the ischemic volume in DW-MRI increased. Additionally, Ahn et al. (27) reported that the IMA index [serum albumin concentration (g/ dL) X23+IMA (U/mL)-100] was more sensitive than the IMA level in ischemic CVD. Also, some studies reported that the clinical condition of the patients with ischemic stroke was positively correlated with the IMA level $(17,19)$. Consuegra-Sanchez et al. (23) reported that the IMA level 
was higher in one-month and one-year mortality. In our study, there were not enough mortal cases and also the study population was low. Further studies with large patient sizes can give better results, especially about mortality.

\section{Study Limitations}

Our most important restrictive reason was that the study was single-centered. Also, late admissions were not included in the study. Moreover, the patients who came with the SVO clinic, patients who did not give consent to be included in the study, and other patients with comorbid diseases were excluded from the study.

\section{Conclusion}

The IMA level can be used in the differential diagnosis of CVD and also positively correlated with ischemic volume. The IMA level may be useful as a new biomarker for the patients who have normal CT results but show clinical symptoms of ischemic CVD.

\section{Ethics}

Ethics Committee Approval: All subjects gave their in formed consent for inclusion before they participated in the study. The study was conducted in accordance with the Declaration of Helsinki, and the protocol was approved by the Ethics Committee of Project identification code: 2013703-04/12/2013.

Informed Consent: It is a prospective study.

Peer-review: Externally peer-reviewed.

\section{Authorship Contributions}

Concept: B.D., M.E.K., Ç.Ç., S.A.U., S.İ., Design: B.D., M.E.K., Ç.Ç., İ.B., S.A.U., S.İ., Data Collection or Processing: B.D., M.E.K., İ.B., C.Y., S.A.U., S.İ., Analysis or Interpretation: B.D., M.E.K., C.Y., K.Ü., İ.B., Literature Search: B.D., A.C., Ç.Ç., K.Ü., C.Y., Writing: B.D., A.C., Ç.Ç., K.Ü., C.Y., S.İ.

Conflict of Interest: No conflict of interest was declared by the authors.

Financial Disclosure: The authors declared that this study has received no financial support.

\section{References}

1. Khaja AM, Grotta JC. Established treatments for acute ischemic stroke. Lancet 2007;369(9558):319-330.

2. Jamieson DG. Diagnosis of ischemic stroke. Am J Med 2009;122(4 Suppl 2):S14-S20.
3. Mullins ME, Schaefer PW, Sorensen AG, Halpern EF, Ay H, He J, et al. CT and conventional and diffusion-weighted MR imaging in acute stroke: study in 691 patients at presentation to the emergency department. Radiology 2002;224(2):353-360.

4. Johnston F, Johnston F, Wardlaw J, Dennis MS, Lewis S, Nimmo G, et al. Delays in stroke referrals. Lancet 1999;354(9172):47-48.

5. Adams HP Jr, Bendixen BH, Kappelle LJ, Biller J, Love BB, Gordon DL, et al. Classification of subtype of acute ischemic stroke. Definitions for use in a multicenter clinical trial. TOAST. Trial of Org 10172 in Acute Stroke Treatment. Stroke 1993;24(1):35-41.

6. Talwalkar SS, Bon Homme M, Miller JJ, Elin RJ. Ischemia modified albumin, a marker of acute ischemic events: a pilot study. Ann Clin Lab Sci 2008;38(2):132-137.

7. Hage V. The NIH stroke scale: a window into neurological status. Nurs Spectr 2011;24:44-49.

8. Sananmuang T, Dejsiripongsa T, Keandoungchun J, Apirakkan M. Reliability of $\mathrm{ABC} / 2$ method in measuring of infarct volume in magnetic resonance diffusion-weighted image. Asian J Neurosurg 2019;14(3):801-807.

9. Hacke W, Kaste M, Bluhmki E, Brozman M, Dávalos A, Guidetti D, et al. Thrombolysis with alteplase 3 to 4.5 hours after acute ischemic stroke. N Engl J Med 2008;359(13):1317-1329.

10. Kolominsky-Rabas PL, Weber M, Gefeller O, Neundoerfer B, Heuschmann PU. Epidemiology of ischemic stroke subtypes according to TOAST criteria. Stroke 2001;32(12):2735-2740.

11. Wira 3rd CR, Rivers E, Silver B, Lewandowski C. Impact of Cardiac Contractility during Cerebral Blood Flow in Ischemia. West J Emerg Med 2011;12(2):227-232.

12. Atkinson RP, DeLemos C. Acute ischemic stroke management. Thromb Res 2000;98(3):97-111.

13. Adams HP Jr, Adams RJ, Brott T, del Zoppo GJ, Furlan A, Goldstein $\mathrm{LB}$, et al. Guidelines for the early management of patients with ischemic stroke. Stroke 2003;34(4):1056-1083.

14. Sacco RL, Adams R, Albers G, Alberts MJ, Benavente O, Furie K, et al. Guidelines for prevention of stroke in patients with ischemic stroke or transient ischemic attack: a statement for healthcare professionals from the American Heart Association/American Stroke Association Council on Stroke: co-sponsored by the Council on Cardiovascular Radiology and Intervention: the American Academy of Neurology affirms the value of this guideline. Stroke 2006;37(2):577-617.

15. Kay R, Wong KS, Yu YL, Chan YW, Tsoi TH, Ahuja AT, et al. Lowmolecular-weight heparin for the treatment of acute ischemic stroke. N Engl J Med 1995;333(24):1588-1594.

16. Kernan WN, Ovbiagele B, Black HR, Bravata DM, Chimowitz MI, Ezekowitz MD, et al. Guidelines for the prevention of stroke in patients with stroke and transient ischemic attack: a guideline for healthcare professionals from the American Heart Association/American Stroke Association. Stroke 2014;45(7):2160-2236.

17. Gunduz A, Turedi S, Mentese A, Karahan SC, Hos G, Tatli O, et al. Ischemia-modified albumin in the diagnosis of acute mesenteric ischemia: a preliminary study. Am J Emerg Med 2008;26(2): 202-205.

18. Lippi G, Montagnana M, Guidi GC. Albumin cobalt binding and ischemia modified albumin generation: an endogenous response to ischemia? Int J Cardiol 2006;108(3):410-411. 
19. Abboud H, Labreuche J, Meseguer E, Lavallee PC, Simon O, Olivot $\mathrm{JM}$, et al. Ischemia-modified albumin in acute stroke. Cerebrovasc Dis 2007;23(2-3):216-220.

20. Sbarouni E, Georgiadou P, Kremastinos DT, Voudris V. Ischemia modified albumin: is this marker of ischemia ready for prime time use? Hellenic J Cardiol 2008;49(4):260-266.

21. Gunduz A, Turedi S, Mentese A, Altunayoglu V, Turan I, Karahan SC, et al. Ischemia-modified albumin levels in cerebrovascular accidents. Am J Emerg Med 2008;26(8):874-878.

22. Turedi S, Patan T, Gunduz A, Mentese A, Tekinbas C, Topbas M, et al. Ischemia-modified albumin in the diagnosis of pulmonary embolism: an experimental study. Am J Emerg Med 2009;27(6):635640.

23. Consuegra-Sanchez LI, Bouzas-Mosquera A, Sinha MK, Collinson PO, Gaze DC, Kaski JC. Ischemia-modified albumin predicts short-term outcome and 1-year mortality in patients attending the emergency department for acute ischemic chest pain. Heart Vessels 2008;23(3):174-180.
24. Fink JN, Selim MH, Kumar S, Silver B, Linfante I, Caplan LR, et al. Is the association of National Institutes of Health Stroke Scale scores and acute magnetic resonance imaging stroke volume equal for patients with right- and left-hemisphere ischemic stroke? Stroke 2002;33(4):54-58.

25. Derex L, Nighoghossian N, Hermier M, Adeleine P, Berthezène Y, Philippeau F, et al. Influence of pretreatment MRI parameters on clinical outcome, recanalization and infarct size in 49 stroke patients treated by intravenous tissue plasminogen activator. J Neurol Sci 2004;225(1-2):3-9.

26. Can S, Akdur O, Yildirim A, Adam G, Cakir DU, Karaman HI. Myelin basic protein and ischemia modified albumin levels in acute ischemic stroke cases. Pak J Med Sci 2015;31(5):110-114.

27. Ahn JH, Choi SC, Lee WG, Jung YS. The usefulness of albuminadjusted ischemia-modified albumin index as early detecting marker for ischemic stroke. J Neurol Sci 2011;32(1):33-38. 